\title{
Constitutionalism: an idea whose time has come ... and gone?
}

\author{
by Harry W Arthurs
}

This article is taken from the John Coffin Lecture in the History of Ideas, which was given by the author at the Institute for Advanced Legal Studies, University of London, on May 13, 2008

\section{THE IDEA OF CONSTITUTIONALISM}

$\mathrm{I}$ intend to talk about the idea of "constitutionalism" as advertised. However, I obviously cannot do justice to the entire history of one of humanity's most sublime conceptions in a mere 50 minutes. Instead, I will single out for special attention a particular model of contemporary constitutionalism - the model that looks to constitutional adjudication as a way of transforming economies and polities, societies and cultures.

While this model is popular today in both legal and non-legal circles, it rests on a number of controversial assumptions: that some authoritative text can be readily identified as a constitution; that it assigns to each of the three branches of government - and different levels of government - distinct and exclusive roles; that it entrenches fundamental rights against abuse by all levels and branches; and that those rights are formally justiciable. It also assumes that jurists - scholars, lawyers and judges - possess a unique institutional and intellectual capacity to comprehend the issues and to apply the constitution to their resolution; that the political culture acknowledges that capacity and accepts constitutional litigation as a sensible way of dealing with transformative change; and that in the end, such litigation actually achieves what it promises.

This court-centred model of constitutionalism is usually draped in the stars and stripes. By contrast, the British model of constitutionalism - at least until recently - has been built around three quite different notions: a largely unwritten constitution, a unitary state and the supremacy of the crown in Parliament. However, things are changing. The British model of the constitution is gradually starting to resemble the American. It is now to be found increasingly in written texts; since 1950 , or at least since 1998, it has partially entrenched human rights and, up to a point, made them justiciable; it has begun to subject Parliamentary legislation to judicial scrutiny; it has taken significant steps towards disentangling legislative, executive and judicial powers; and - further evidence of Americanization - it is slowly drifting towards federalism, albeit of a highly asymmetrical variety. Finally, many British jurists - but also political scientists, journalists, activists and ordinary citizens - seem to be attracted by the prospect that fundamental rights will be constitutionally entrenched and by the heroic litigation and transformative adjudication that entrenchment supposedly portends.

For a Canadian, these British developments have a particular resonance. After all, when our federation was formed in 1867, we expressed our desire to unite under "a constitution similar in principle to that of the United Kingdom". Ironically, we re-affirmed that desire as recently as 1982 at the very moment when we severed our last constitutional ties with Westminster, adopted a madein-Canada constitution, declared it the supreme law of the land, entrenched in it a Charter of Rights and Freedoms, and by all doing these things, moved ourselves significantly away from the British and towards the American model of constitutionalism. And to compound the irony, the United Kingdom itself seems no longer committed to a "constitution similar in principle" to the one before which Canadians have twice genuflected, and genuflect still, in the preamble to their fundamental law.

This represents a quick summary of the first part of my lecture, which I lack the time to deliver in full this evening. I know that what I have said is contentious and that many of you will rightly demand to be given chapter and verse, which I will provide when I revise my text for publication. For now, I can only ask you to willingly suspend disbelief 
and accept provisionally what I have said about developments in the United Kingdom and Canada.

As for the remaining parts of my lecture, those you will have to endure more or less in full. In the second part I try to explain why American-style court-centred constitutionalism is an idea whose time has come. In the third, I suggest that this idea, this model, of constitutionalism cannot be sustained - that written texts, entrenched rights and constitutional litigation do not and cannot actually contribute much to fundamental social and political transformations. And in the fourth and final part of the lecture, I propose a moral to my story.

\section{WHY CONSTITUTIONALISM? WHY NOW?}

So, why constitutionalism, and why now? I am going to propose a number of possible explanations.

\section{The ascent of civilization}

The first, which should appeal to the Whigs amongst you, is that the ascent of society from status to contract, first detected by Sir Henry Maine, continued on an inexorable upward trajectory from contract to legislation, and thence from legislation to constitution - whence it could progress no further. The example par excellence of the constitutional state is, on this view, America - that shining city on the hill - whose glorious judge-led civil rights revolution transformed it in the 1950s, "60s and '70s. Or so it seemed to those of us whose legal hormones were stirred, whose scholarly imaginations were shaped, whose juridical utopias were defined by Brown v Board of Education and Roe v Wade.

Woodsworth said it first and best:

Bliss it was in that dawn to be alive,

But to be young was very heaven! - Oh! Times,

In which the meagre, stale, forbidding ways

Of custom, law and statute took at once

The attraction of a country in romance!

But like Woodsworth's revolutionary France, the Warren Court's America soon ceased to be "a country in romance”. In just this past decade, its Supreme Court has legitimated an illegitimate presidency; has signalled that it is bored with Brown and determined to abort Roe; and has been complicit in both the post-9/11 shock-and-awe invasion of civil rights, and the neo-conservative surge offensive against the last vestiges of Franklin Roosevelt's New Deal and Lyndon Johnson's Great Society.

\section{Disillusion with electoral politics}

A second, more likely, explanation for the increasing appeal of constitutional adjudication as an instrument of progressive reform is widespread disenchantment with Parliament, with parties and with electoral politics. People do not participate in civic activities; they are not politically engaged; they do not even bother to vote.
Some blame the decline of Parliamentary democracy on the social compression of time; others on the loss of cultural homogeneity and social cohesion; others on the rise of race and gender identity politics, on the dumbingdown of the educational system, on the manipulation of the media, on the baleful influence of corporate money and lobbyists, on the abandonment by the mainstream parties of ideological coherence and moral integrity, on inherent flaws in our electoral processes and legislative institutions.

Whatever the cause, the outcome seems clear enough: supporters of progressive causes in particular seem to be turning increasingly to constitutional litigation - rather than to social or political mobilization - in order to achieve their goals. If human and social rights were formally constitutionalized, they reckon, the courts would enforce them; if the courts enforced them, governments would have to implement them; and if governments implemented them, society would be transformed. So reasonable, so simple, so quick, so cheap, so sure.

Now, one can understand why constitutional litigation appeals to those who have grown weary of unrewarding drudgery on the New Jerusalem building site. One can understand, too, why if rights are to hand, anyone might be tempted to launch opportunistic litigation to liberate asylum seekers, nab touring dictators, secure social benefits for claimants improperly denied them or forestall prison brutality, nuclear war and environmental degradation. One cannot understand, however, why so few progressive people detect the delicious irony of confiding the fate of social and individual rights to judges who were rightly regarded - until quite recently and with honourable exceptions - as the very epitome of entrenched conservatism.

\section{Neo-liberalism}

Mind you, the irony has not escaped everyone. Many neo-liberals have also become keen on constitutionalism. They imagine that constitutions can function as a "bridle for Leviathan", a device to reign in the great beast of state regulation and benefaction which, for 200 years, has pulled forward the project of progressive politics.

How does Levianthan's bridle work? By protecting property from uncompensated regulatory "takings"; by requiring administrative tribunals to adhere to "fair" which is to say court-like - procedures notoriously unsuited to the business at hand; by subjecting complex state policies to simple-minded judicial review on grounds of "reasonableness" or "substantive fairness" or "proportionality"; by dispersing state powers vertically amongst competing national, sub-national and supranational jurisdictions and horizontally amongst the three branches of government; and - all else failing - by 
providing corporations with opportunities for endless, debilitating legal challenges to all forms of regulation.

Most of all, however, constitutionalism constrains activist governments by changing our understanding of the state and the relationship of citizens to it. Citizens, in the neo-liberal view, come in two varieties, human and corporate, and both are rights-bearing market actors, rather than members of a political community. The emphasis, accordingly, is on the constitutional vindication of individual rights through litigation, rather than of collective interests through political action.

Neo-liberals also believe that the ideal state is the minimal state. By this standard, courts - "the least dangerous branch" - have advantages over the other institutions of government. They are relatively cheap to operate, but deter over-use by the judicious imposition of costs. They are procedurally passive, at least in the common law world, and cannot initiate claims, search out evidence, hire experts, invent arguments or even enforce their own decrees. Their interventions are episodic rather than strategic, situational rather than systemic. They appear to offer definitive answers to questions which are, alas, too complicated for such answers. Not without reason, then, do neo-liberals laud the judiciary as the guarantor of the state's sovereignty, legitimacy and fundamental values.

\section{Globalization}

Neo-liberalism bears the same relationship to globalization as cleanliness does to godliness. That is why I must say something next about the contribution of globalization to the current popularity of constitutionalism. Three quick points:

The first is that the global economic order, carrying on business under the name and style of the Washington Consensus, has become publicly committed to "good governance". One aspect of good governance is the existence of an independent judiciary capable of enforcing fundamental rights. Why should this be so? Because well-governed states are likely to be relatively stable and hence safe for business, and because if property rights are acknowledged as "fundamental" or "inviolable", the courts can protect foreign investors against confiscation or regulation by nationalist or activist governments.

Second, the elaborate structure of treaties and conventions which holds the global economy together might itself be regarded as a constitution. Like domestic constitutions, it entrenches a new legal logic in which the economic trumps the social and the cosmopolitan trumps the parochial. Like domestic constitutions, it imposes juridical limits on national legislation. And like domestic constitutions, the constitution of the global economy purports to replace power with the rule of law and crass politics with principled adjudication. This extended constitutional metaphor - which has been used, for example, by the architects of the World Trade Organization - may have been intended to legitimate and operationalize globalization; but it has had the unintended effect of making powerful and influential people hostage to the fortunes of constitutionalism.

A third and final link between globalization and constitutionalism is the process I refer to as "globalization of the mind". A consensus has developed amongst rightthinking people in most developed countries - including yours and mine - that "we are all neo-liberals now". For odd and dubious reasons, as I have suggested, this consensus view has come to include a commitment to court-based constitutionalism. However, a movement of critique and resistance has also emerged - a counterconsensus if you will. That counter-consensus, in an equally odd and dubious fashion, proposes that if human, social and labour rights were somehow embedded in the constitution of the global economy, if they were inscribed in the fundamental documents governing regional trade regimes such as NAFTA and the EU, if they were accepted as universal norms immanent in all forms of international ordering, if - especially - they were acknowledged and enforced by competent trade tribunals, neo-liberalism would have to harken to the better angels of its nature.

Would that it were so. In the next part of my lecture, I am going to try to persuade you that even welldeveloped domestic systems of constitutional adjudication do not actually accomplish very much. If that is so, why should we expect more from global systems?

\section{DOES CONSTITUTIONALISM ACTUALLY MATTER - AND IF NOT, WHY NOT?}

To frame the debate in this third part of my lecture, I am going to ask a bold question: does constitutionalism actually matter? Do countries which entrench fundamental rights and empower their courts to enforce them in fact experience more equality, more democracy, more social justice than they would otherwise have done? That is a difficult question in itself, but if the answer is "yes", one must then ask an even harder question: is the constitutionalization of rights in those countries a cause or an effect of their democratic character?

Based on the experience of the United States, one would have to say that constitutionalism probably does not matter. Here is a country with the longest experience of court-centred constitutionalism, with the most principled constitutional judges, the most ambitious constitutional litigators, the most sophisticated constitutional jurisprudence, the most profound constitutional scholarship, the most-rights conscious citizenry, the strongest tendency to place rights discourse and litigation at the centre of its political culture. And what does it have to show for it? Arguably, the most 
egregious social inequality of any advanced democracy, the lowest level of engagement in democratic politics, the most heavy-handed police forces, capacious prisons and over-worked executioners, and the greatest willingness to tolerate cruel, coercive and intrusive state action in the name of "homeland security".

I leave it to members of this audience to say whether the United Kingdom has become a less repressive state, a more equal society and a more vibrant democracy, since its accession to the European Convention on Human Rights in 1950 or its enactment of the Human Rights Act of 1998. I suspect that at least some of you would respond that in recent years there has been a massive increase in state surveillance and coercion, a declining tolerance for free speech and deviant beliefs and behaviour, and diminishing accountability for the abuse of state power. As for Canada, I can only report that I have recently been conducting empirical research into the social - as opposed to juridical - effects of our Charter of Rights and Freedoms, which was adopted in 1982. Making due allowance for serious methodological difficulties, my study suggests that the effects of the Charter are barely discernible: a little forward movement here, a little backsliding there; but in general the Charter has transformed legal practice, discourse and thought far more thoroughly than it has the quality of life of its intended beneficiaries.

Perhaps there are counter-examples: India and South Africa come to mind, and possibly Germany. Each of these countries adopted a new constitutional regime when it reinvented itself in the aftermath, respectively, of colonialism, apartheid and national socialism; each opted for entrenched human, political and social rights; and each entrusted enforcement of those rights to a judiciary which has often, if not always, applied them energetically and imaginatively. However, the question remains: to what extent has constitutionalism - entrenched rights and judicial review - actually contributed to social, political or economic transformation?

That is an empirical question. However, empirical evidence is hard to come by; and even if we could find some, it would not necessarily support generalizations about constitutionalism since each polity, economy, society and legal culture is the product of unique and complex historical circumstances. Nonetheless, if we cannot hope to find general answers, at least we can legitimately ask a few more pointed questions. To what extent did the Constitutional Court of South Africa enhance that country's already ambitious housing program, when it famously ruled in 1998 that Mrs Grootboom's children had a right to adequate housing? ${ }^{1}$ How many people were rescued from starvation as a result of the heroic dictum of the Indian Supreme Court that

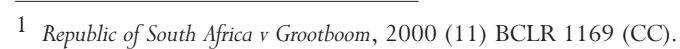

they were constitutionally entitled to at least "the bare necessities of life" ? ${ }^{2}$ If these judgments did have any longterm, systemic consequences beyond securing relief for the litigants, there ought to have been a blip in housing starts, a dip in rates of malnutrition. However, I suspect that such blips and dips will have been no more in evidence in India and South Africa than they have been in Canada since the adoption of our Charter.

And why not? Because constitutional litigation has only a marginal effect on public policy, practical governance and the allocation of public goods.

Remember: constitutional litigation does not launch itself. Someone has to sue. If that person is a corporation or a wealthy individual, they are not likely to be seeking to vindicate human rights, cure social wrongs or protect the general public interest. If the plaintiff is the sort of person who is usually victimized by "the system" someone who typically cannot afford to sue - the burden of financing the litigation will fall either on an advocacy group or on the state itself. However, because advocacy groups are committed to their cause, they tend to make strategic and tactical judgments about whom to represent, when to litigate and what arguments to make. Any of these judgments may skew the way in which issues are presented and perceived. And as for state funding of constitutional litigation, you may be interested to know that after twentyodd years of funding so-called "Charter challenges", Canada's federal government recently decided that it had other spending priorities. This decision will ultimately have a huge effect on the volume, character and outcomes of Charter litigation - though probably not on everyday life.

Moreover, constitutional litigation is better designed to remedy individual injustices than to correct systemic wrongdoing. The nominal plaintiff may frame the issues in a particular way because of their personal circumstances, to meet procedural or evidentiary requirements, or in order to be able to rely on a more promising constitutional principle rather than a less promising one. However, the way in which issues are framed also determines the relevance of evidence and the cogency of arguments advanced by the parties, not to mention the grounds upon which judges must ultimately dispose of them. As a result, the courts are almost certain to possess a distorted and incomplete understanding of the system which the litigation is designed to challenge.

The parties - the plaintiff or the government - may seek to overcome these deficiencies in what the court knows, and in the issues it can address, in several ways. They may file affidavits from expert witnesses which provide background information about the larger issues. Counsel in argument may point to the dangers of falling

2 Mullin v Administrator, Union Territory of Delhi AIR 1981 SC 746. More ambitious, ongoing litigation on the "right to food" has resulted in specific remedial orders. See PUCL $v$ Union of India and others (Writ petition [Civil] No 196 of 2001) and http://www.righttofoodindia.org/case/case.html 
skies, slippery slopes or opening wedges - to the potential harm to citizens, the state or the law. Or judges may take judicial notice of missing information. None of these is really satisfactory. Affidavits are typically designed to persuade, not enlighten; and judges lack both the means and the mandate to verify, challenge or supplement the information they contain. Counsel can make arguments about the issues before the court but not - with propriety - about issues which are not being litigated, even though they may be affected by the outcome. And judges may be entirely mistaken in their personal understanding of how a system operates or what will be the effect of changing it. For all of these reasons, it is highly likely that courts will either overestimate or underestimate the consequences of their rulings.

The third consideration has to do with the remedial power of courts. Many of the most egregious and deeply entrenched injustices have to do with the maldistribution of power and money. Courts have little or no power to correct that maldistribution. However, unless welfare systems, schools, hospitals, police forces, prisons, immigration offices and other state agencies are given unlimited resources, to remedy an injustice by ordering that the plaintiff be treated properly is to run the risk that someone else will bear the brunt. I do not myself shrink from saying these organizations ought to be given more resources, or that those which exist ought to be distributed according to a different principle than the one which a court has ruled constitutionally illicit. But courts typically do shrink from those kinds of statements. They certainly will not order that taxes or rates should be increased; or that the budget of one program ought to be cut so that another can be augmented; or that the plaintiff's needs ought to be met at the expense of someone else similarly situated.

Nor could they possibly make those orders, even though such outcomes are almost inevitable. Rather, courts tend to say to government, "we have decided that what you have done is wrong; fix it; it's up to you to figure out how." Taking an optimistic view of the matter, such an admonition often initiates what one distinguished Canadian constitutionalist calls a "dialogue", between courts and governments. And often governments do find a way to "fix it", he notes, though occasionally they fail or decline to do so, with the consequence that the court must intervene with more specific instructions. But that is not the whole story. Governments also find ways not to "fix it", to continue the very behaviour the court has struck down. Of course plaintiffs will get their personal remedy if they win their case. However, governments may pay lip service to the general principle behind the court's ruling, and then find alternative ways to do what the principle forbids, or simply ignore the ruling altogether secure in the knowledge that it will be some time before new litigation can be mounted. These inherent limits on the remedial power of the courts may help to explain why our Charter has had such limited practical impact.

The next institutional obstacle to the use of constitutional litigation to achieve transformative social outcomes is the character of judges and the nature of the adjudicative process. Judges are mainly conservative by instinct and training. Whatever their personal political predilections, they must adhere to a fairly rigid juridical canon; they live within an intellectual tradition which emphasizes continuity and a professional culture which embraces circumspection; they are therefore professionally programmed to prefer ancient privileges over novel claims and established rights over pragmatic solutions; and - while idiosyncrasies of style and rhetoric are indulged, even prized - judges routinely employ symbolic behaviours and discursive strategies which make their judgments appear neutral, principled, reasonable and inevitable rather than what they really are: value-laden, result-driven, contested and contingent.

I draw breath here not only to await chastisement or worse from our distinguished and honourable chair, Lord Hope, but also to concede several important points. Not all judges are conservative in either a legal or political sense; nor do they all willingly accept the limitations of ancient precedents and traditional processes; nor - when they have taken off their gowns and wigs - do they all deny that contingent circumstances and the search for just and practical outcomes shape decisions as much as the application of legal rules and constitutional principles. But in conceding these points, in acknowledging that many judges are progressive political actors, well aware that they are making choices rather than following rules, I am also stripping constitutional adjudication of some of its mystique and its utility.

Mystique first: if decisions about fundamental rights are always and inevitably political in nature, why prefer clandestine political decision-makers to those who are democratically elected and accountable? And utility next: what use is constitutional adjudication if it is not what it appears to be, if it is, after all, the rule of judges however well-intentioned, and not the rule of law however ill-considered? These questions, or similar, help to explain the unseemly struggle to fill the United States Supreme Court with judges who favour or disfavour abortion, affirmative action, executive privilege, theocracy and torture. That struggle for judicial appointments, in my view, gives the lie to claims that constitutional litigation exists on a higher plane than ordinary political controversy.

This last point leads me to a final and more fundamental challenge to court-centred constitutionalism. It is, in a way, oddly oblivious to the great controversies in legal thought which have preoccupied scholars over the past century or more. Let me explain. Constitutionalism assumes that law can and does shape society, that it changes minds, that it redistributes resources, that it recalibrates 
power. However, since at least the $19^{\text {th }}$ century critics have persuasively argued - some would say "clearly demonstrated" - that to the contrary, law is shaped by society, by culture, by political economy. Constitutionalism assumes that adjudication is a rational and principled exercise. However, since the $19^{\text {th }}$ century, critics have contended that constitutional adjudication is the continuation of politics by other means, that in deciding controversial cases judges are heavily influenced by their own ideological predilections, and that they act in fairly predictable alliances with like-minded colleagues.

These two critiques are at odds with each other. The first discounts the effects on society of constitutional adjudication - and of law in general; the second treats law - especially constitutional adjudication - as a crucial site of social, cultural and political contestation. However, both challenge the claim that because constitutionalism is ultimately "legal", it is necessarily rational, principled, efficacious and legitimate, let alone indispensable to the governance of modern democracies.

To be sure, practitioners and proponents of constitutionalism make several responses to this challenge.

The first proceeds from a fundamental principle: that majoritarian politics ought not to trump other core values - such as justice and equality - which are firmly entrenched in the constitution alongside the right to speak, assemble or vote. By enforcing respect for the rule of law and constitutional rights, courts ensure that these other values will not be overridden by 50 per cent plus one of the electorate or a simple majority in Parliament. The second response is more pragmatic: that constitutional adjudication, far from challenging electoral democracy, makes it possible; that courts ensure the necessary preconditions for democratic politics by holding other state institutions to high standards of fairness, openness and accountability; and that courts offer practical recourse to individuals and small communities who cannot attract the attention or support of more broadlybased political parties and social movements. In support of these first two claims, supporters of constitutionalism remind us that judges consistently rank at the top of surveys which measure public esteem and that Charters or Bills of Rights enjoy similarly high levels of public support.

The third response is a more subtle version of the second: that the real effects of constitutionalism are not so much juridical as cultural; that by affirming human rights and civil liberties, courts legitimate both their practice and their advocacy; that the very adoption of a Human Rights Act or its equivalent transforms political discourse, legislative drafting and administrative behaviour; that the discourse of rights permeates spheres of social interaction from business practice to popular culture.
I acknowledge that these defences of constitutionalism deserve serious consideration; and they will receive it in the final version of my lecture. But if I spent the rest of our time together confronting them, I would neither persuade you nor reach what, for me, is the real point of the debate over constitutionalism and of this lecture. That point, by a happy coincidence, has to do with the common project of our hosts, the John Coffin Lectureship and the Institute of Advanced Legal Studies. It is this: How does one think about an idea? And more specifically, how does one evaluate claims and resolve disagreements about legal ideas?

\section{WHAT CONSTITUTIONALISM TELLS US ABOUT LEGAL THOUGHT}

If I were lecturing this evening on the beneficial effects of bloodletting or the healing properties of eye of newt, you would rightly ask me for evidence. If I produced "evidence", you would then do two things. First, you would ask whether the same evidence is consistent with other hypotheses; and second you would ask what theory of causation might explain the beneficial outcomes I have claimed for these unorthodox forms of medical intervention. However, most lawyers and judges - and most legal scholars - are unlikely to ask similar questions about the effects of constitutionalism.

In a series of epidemiological studies beginning in the 1960s - the so-called Whitehall Studies - the class background of entrants to the British civil service was identified as a strong predictor of their health outcomes and career achievements. A number of plausible hypotheses have been advanced to explain why: rich people's children eat better when they are young so they are more likely to be healthy later in life; they are more likely to receive intellectual stimulus in early childhood, so their brains are "hard-wired" for better performance at school and at work; these advantages - reinforced, of course, by class prejudice - improve their chances of securing attractive entry-level jobs; and the same qualities give them an edge in securing promotion to challenging senior positions which, in turn, provide a degree of job satisfaction which contributes to their improved morbidity and increased longevity. Empirical studies of the social determinants of health apparently confirm many of these hypotheses.

Now let us conduct a thought experiment. What would a similar study of the social determinants of human, social and political rights reveal? From the fragmentary evidence available, I suspect it would show that class background correlates closely with the enjoyment of all public goods - of access not only to education, health services, housing and public sector jobs, but to participation in civic, and cultural life and to the enjoyment of human, social and political rights. In other words, the disadvantages poor people suffer in health and career outcomes is in all probability replicated in other areas of their lives. They 
are more likely to encounter abuse at the hands of the police, welfare authorities and other state functionaries; they are more likely to experience discrimination in the workplace; they are less likely to exercise their freedom to speak, associate, assemble, run for office or vote; and they are less likely to recognize that they have constitutional or other rights, let alone to seek, receive or act on legal advice to vindicate those rights.

If evidence to this effect could be developed, it would be crucial to any evaluation of claims that the constitutional entrenchment of rights and access to effective adjudication will improve the lot of the most vulnerable people in our society. But astonishingly, there is no Whitehall study on the social determinants of legal rights. There is indeed no developed science of legal epidemiology which would enable a Whitehall study to be undertaken. Absent such a study, we lawyers tend to settle for assumptions: that constitutionalism can make a difference; that clever advocacy, heroic judging and elegant scholarship can make a difference; that we can make a difference. These are high-minded assumptions to be sure, but they are assumptions which are largely unexplored, likely unsupportable and, ultimately, selfreferential.

It turns out, then, that the history of the idea of constitutionalism is not so much about specific legal concepts, forms or practices. It is rather about us and about how we think about law. In the carrels and offices, in the reading rooms and lecture halls, of the Institute of Advanced Legal Studies, for the past sixty years, that is what people have been doing: thinking about law. The ambition of this lecture has been to persuade them to do so in a spirit of greater self-awareness and openmindedness; to test even the most cherished and noble assumptions about legal ideas, institutions and processes more rigorously and empirically; and - yes, I confess - to explore claims about the transformative potential of constitutionalism with mischief aforethought.

This lecture began life as the Lord Morris of Borth-y-Gest Lecture presented at the Faculty of Law, University of Cardiff in 2003. It has metamorphosed considerably thanks to provocative and helpful suggestions from Roderick Macdonald, Lorne Sossin and Jeremy Webber.

\section{Harry W Arthurs}

University Professor of Law and Political Science Emeritus

And President Emeritus, York University, Toronto, Canada 